\title{
Bioaccumulation of decabromodiphenyl ether affects the antioxidant system in the clam Mactra veneriformis
}

\author{
$\mathrm{Na} \mathrm{Zhu}^{\mathrm{a}}$, Yanyan Yang ${ }^{\mathrm{b}}$, Hua Xuc ${ }^{\mathrm{c}}$, Qing Wang ${ }^{\mathrm{d}}$, Yanyan Wei ${ }^{\mathrm{a}}$, Mingzhu $\mathrm{Li}^{\mathrm{a}}$, Fan $\mathrm{Li}^{\mathrm{b}}$, Yiqi Wang ${ }^{\mathrm{a}}$, \\ Huawei Zhang ${ }^{\mathrm{b}}$, Yihao Liu ${ }^{\mathrm{b}}$, Xiaomeng Wang ${ }^{\mathrm{a}}$, Yan Fang ${ }^{\mathrm{a}, *}$ \\ ${ }^{a}$ School of Agriculture, Ludong University, Yantai, 264025, China \\ ${ }^{\mathrm{b}}$ Shandong Provincial Key Laboratory of Restoration for Marine Ecology, Shandong Marine Resource and Environment Research Institute, Yantai, 264006, China \\ ${ }^{c}$ Yantai Environmental Monitoring Center, Yantai, 264000, China \\ ${ }^{\mathrm{d}}$ Yantai Institute of Coastal Zone Research, Chinese Academy of Sciences, Yantai, 264003, China
}

\section{A R T I C L E I N F O}

\section{Keywords:}

Decabromodiphenyl ether

Antioxidant enzymes

Bioaccumulation

Mactra veneriformis

\begin{abstract}
A B S T R A C T
Antioxidant enzymes play vital roles against oxidative stress induced by decabromodiphenyl ether (BDE-209), being widespread in marine environment. However, the effect of BDE-209 on antioxidant enzymes remains poorly understood in marine bivalves. In this study, the clams Mactra veneriformis were exposed to $0.1,1$, and $10 \mu \mathrm{g} / \mathrm{L}$ BDE-209 for 7 days and then maintained in clean seawater for 3 days as the depuration. The bioaccumulation of BDE-209 and the effects on superoxide dismutase, catalase, and glutathione peroxidase were investigated. BDE-209 accumulation was concentration-dependent and decreased by $36 \%-52 \%$ after recovery. Malondialdehyde contents increased in a time- and dose-dependent manner. mRNA expression and activity of antioxidant enzymes changed with different patterns and recovered after depuration. These results suggested that antioxidant systems were triggered to protect the clams from oxidative damage caused by BDE-209. Thus, this research is helpful in elucidating the effect of BDE-209 on antioxidant system in marine bivalves.
\end{abstract}

\section{Introduction}

Polybrominated diphenyl ethers (PBDEs) are aromatic compounds containing bromine atoms, and 209 PBDEs congeners vary by the number and position of bromine atoms in the benzene ring. PBDEs have been widely used as flame retardants in industrial and consumer products such as textiles, furniture, plastics, printed circuit boards, and building materials (de Wit et al., 2010). Commercial PBDEs are typically pentabromodiphenyl ether (PentaBDE), octabromodiphenyl ether (OctaBDE), and decabromodiphenyl ether (BDE-209). BDE-209 and PentaBDE have been listed as persistent organic pollutants by the Stockholm Convention (Stockholm Convention, 2018). Although bills have been introduced by the European Union, the United States, and Canada to prohibit the use of PentaBDE, OctaBDE, and BDE-209, the latter is still produced and used in multiple areas (Akortia et al., 2016).

PBDEs can be easily released into the environment during production and use, polluting ecosystems. PBDEs have been detected in a variety of environmental media and organisms, including seawater, sediment, air, shellfish, human, polar bear, and Antarctic penguin (Jin et al., 2008; Krieger et al., 2016; Mwangi et al., 2016; Roscales et al., 2018; Zota et al., 2018). BDE-209 is the dominant PBDEs congener found abundantly in the environment and biota. The ocean is the final destination of many pollutants, and PBDEs pollution has been recorded in marine environments worldwide, and is especially common in China. Concentrations of PBDEs in sediments and shellfish have been shown to be as high as $1800 \mathrm{ng} / \mathrm{g}$ dry weight and $720 \mathrm{ng} / \mathrm{g}$ lipids, respectively, in Laizhou Bay, around by multiple flame-retardant production plants (Jin et al., 2008). In the surface sediments and waters of Dongjiang River in the Pearl River Delta, where the largest global electronics production base is located, BDE-209 concentrations reached $7340 \mathrm{ng} / \mathrm{g}$ dry weight (Mai et al., 2005) and 65.2 ng/L (Guan et al., 2007), respectively. The toxicity and environmental behavior of BDE-209 have been studied less than those of low-brominated congeners. BDE-209 is known to exert toxic effects on the endocrine, nervous, cardiac, and reproductive systems in rats, zebrafish, and other terrestrial or freshwater vertebrates (He et al., 2011; Milovanovic et al., 2015; Zhu et al., 2016; Han et al., 2017), while less attention has been paid to the impacts of BDE-209 on marine organisms. The toxic effect of PBDEs is yet to be fully explored in the marine organisms.

Bivalves are a good indicator of marine environmental pollution, and offer a powerful tool in toxicological research. Shellfish biomonitoring programs are widespread. For example, the United States' Mussel

\footnotetext{
* Corresponding author.

E-mail address: fly12689@163.com (Y. Fang).
} 
Watch Program, which began in 1986, has analyzed more than 100 pollutants in bivalve tissues collected along coastal and Great Lake waters (Bricker et al., 2014). The Asian Mussel Watch Program, which was launched in 2003, was designed to monitor PBDEs and organochlorine pesticides in the coastal waters of Asian countries; BDE-209 has been measured in offshore mussels from China, South Korea, Japan, and Indonesia, suggesting that BDE-209 pollution is widespread in the marine environments of these countries (Ramu et al., 2007).

The good correlation has been found between effects of organic pollutants in mussels and effects of the same pollutants in humans, which indicates that these pollutants can affect the whole food chain (Van Beneden, 1994). Therefore, the study of the effects of PBDEs on shellfish may provide useful information of the effects of PBDEs on other organisms and on whole ecosystems (Barón et al., 2016). Barón et al. (2016) evaluated the genotoxicity and growth effects of BDE-209 on the mussel Mytilus galloprovincialis and found DNA damage and micronuclei formation. Mussels, however, are not highly distributed in the tidal flat areas that lack attachments, requiring a different indicator organism for toxicological research and environmental monitoring in these ecosystems, to provide scientific data for PBDEs ecological risk assessment. Mactra veneriformis is an infaunal suspension-feeding bivalve, widely distributed in the coastal areas of China, Japan, and South Korea, and is of economic importance in China. The clam can efficiently accumulate pollutants, and has evolved to respond to pollutants rapidly (Wang et al., 2005; Fang et al., 2010; Shi et al., 2018), making it a good candidate of experimental organism in toxicology research.

Oxidative stress is a known pathway of pollutant toxicity, and studies have shown that BDE-209 can stimulate the production of reactive oxygen species (ROS), leading to oxidative stress (Milovanovic et al., 2015; Zhang et al., 2016a). The antioxidant system can scavenge ROS and protect the body from oxidative damage using enzymes such as superoxide dismutase (SOD), catalase (CAT), and glutathione peroxidase (GPx). These enzymes in aquatic animals are sensitively responsive to PBDEs and considered as biomarkers of water pollution (Xie et al., 2014; Horion et al., 2015; Shenai-Tirodkar et al., 2017). However, to our best knowledge, few studies have focused on the effect of BDE-209 on antioxidant enzymes in marine bivalves.

The present study aims at elucidating the effect of BDE-209 on antioxidant systems in M. veneriformis. Clams were exposed to BDE-209 for 7 days and recovered in clean seawater for 3 days. First, the bioaccumulation of BDE-209 and the level of oxidative damage marker malondialdehyde (MDA) were measured to assess the oxidative stress caused by BDE-209. Then, the gene expression and enzyme activities of SOD, CAT, and GPx were determined in the digestive gland. Third, the correlations between antioxidant response, MDA level, and BDE-209 concentration were analyzed. Thus, this study benefits the toxic effect of BDE-209 on marine shellfish and facilitates ecological risk assessment of offshore PBDEs pollution.

\section{Materials and methods}

\subsection{Clams and exposure}

Adult $M$. veneriformis were collected from the Dongying coastal area (average shell length $3.77 \pm 0.28 \mathrm{~cm}$; shell height $3.15 \pm 0.31 \mathrm{~cm}$; shell width $2.46 \pm 0.38 \mathrm{~cm}$; weight $12.93 \pm 0.52 \mathrm{~g}$ ) and acclimated for 14 days in our laboratory. Healthy and regular-shaped M. veneriformis were placed into glass aquariums at random; each aquarium was loaded with $30 \mathrm{~L}$ seawater and 60 clams. One control group, one solvent control group, and three exposure groups were included, for a total of six replicates for each group. In order to identify the uptake of the contaminant by clams and possible losses of the contaminant, three blank groups without clams corresponding to three exposure groups were also set up. BDE-209 concentrations in blank groups were same as that in exposure groups.

DNA damage and micronuclei formation were induced in $M$. galloprovincialis exposed to 0.03 and $0.3 \mu \mathrm{g} / \mathrm{L}$ BDE-209 for 6 days (Barón et al., 2016). Exposure to 0.004 and $0.04 \mu \mathrm{M}$ (3.884 and $38.84 \mu \mathrm{g} / \mathrm{L}$ ) BDE-209 for 7 days increased hepatic GPx activity in Carassius auratus (Zhao et al., 2011). The bioaccumulation of BDE-209 increased with time in Japanese medaka Oryzias latipes under the exposure concentration of $0.001-1 \mu \mathrm{g} / \mathrm{L}$ (Luo et al., 2013). Parental exposure to environmentally relevant concentrations of PBDEs $(0.16,0.8$, $4.0 \mu \mathrm{g} / \mathrm{L}$ ) adversely affected the neurodevelopment of zebrafish offspring (Chen et al., 2012). Accordingly, 0.1-10 $\mu$ g/L BDE-209 could be accumulated in aquatic animals and cause toxicological effect. Furthermore, the concentrations of 0.1 and $1 \mu \mathrm{g} / \mathrm{L}$ were in the same order as BDE-209 contents in coastal waters and sediments (Mai et al., 2005; Guan et al., 2007; Cristale et al., 2013). Although higher than those detected in waters (Guan et al., 2007), the concentration of $10 \mu \mathrm{g} / \mathrm{L}$ was often used for short-term exposures to produce distinctly identifiable effects. To identify the effects of BDE-209 on antioxidant system in $M$. veneriformis and compare these effects with that on other species, exposure concentrations of $0.1,1$, and $10 \mu \mathrm{g} / \mathrm{L}$ were used in this study.

A stock solution of $1 \mathrm{~g} / \mathrm{L}$ was prepared by dissolving BDE-209 (CAS No. 1163-19-5, purity $>98.5 \%$, AccuStandard Inc, New Haven, CT, USA) in dimethyl sulfoxide (DMSO, Sinopharm Chemical Reagent Co., Beijing, China), and added to the aquariums to obtain the required concentrations and $0.05 \% \mathrm{v} / \mathrm{v}$ DMSO. In the solvent control group, only DMSO was added at a final concentration of $0.05 \% \mathrm{v} / \mathrm{v}$. In the control group, only natural seawater was added. The aquariums were continuously aerated throughout the experimental period, the water was changed every day at a fixed time, followed by the addition of the relevant volumes of BDE-209 and DMSO, and the clams were fed with the algae Nitzschia closterium at an approximate concentration of $1 \times 10^{5}$ cells $/ \mathrm{mL} 2 \mathrm{~h}$ before the water change. The experimental conditions were as follows: Dissolved oxygen, 7.7-8.2 mg/L; pH, 8.1; salinity, 31; temperature, $16 \pm 1{ }^{\circ} \mathrm{C}$. The seawater was sampled immediately after $(0 \mathrm{~h})$ and before $(24 \mathrm{~h})$ water change, and BDE-209 concentrations were measured.

The experimental period lasted 10 days. Clams M. veneriformis in the exposure groups were exposed to BDE-209 for 7 days and recovered in clean seawater for 3 days, while the clams in the control group and the solvent control group were cultured in clean seawater and seawater containing DMSO $(0.05 \% \mathrm{v} / \mathrm{v})$ for 10 days, respectively. On days $0,1,3$, 5,7 , and 10 , the digestive glands of the clams were isolated. Half of the digestive gland from one clam was used to measure mRNA levels, and the other half was used to measure enzyme activities and MDA content. Digestive glands from 10 clams were pooled into one replicate, and 3 replicates were performed for each experimental group at each sampling point. Thus, 30 clams from each experimental group were sampled at each sampling point, and 180 clams from each experimental group were sampled at all the sampling points. On days 7 and 10, extra digestive glands were sampled to measure BDE-209 accumulation. Digestive glands from 20 clams were pooled into one replicate, and 3 replicates were performed for each experimental group at each sampling point. Thus, 60 clams from each experimental group were sampled at each sampling point, and 120 clams from each experimental group were sampled at all the sampling points. Taken together, 300 clams were sampled in each experimental group during the whole experiment. All the samples were rapidly frozen in liquid nitrogen and stored at $-80^{\circ} \mathrm{C}$.

\subsection{Measurement of BDE-209 concentrations in seawater and clams}

BDE-209 contents in seawater and clam samples were determined by gas chromatography-mass spectrometry according to the method of Sha et al. (2015) with some modifications. Seawater samples were extracted twice with dichloromethane (HPLC grade, Sinopharm Chemical Reagent Co.), then evaporated at $40^{\circ} \mathrm{C}$ by rotary evaporator (Büchi Rotavapor R-200, Flawil, Switzerland). After re-dissolving the samples using n-hexane (HPLC grade, Sinopharm Chemical Reagent Co.), 
anhydrous sodium sulfate (HPLC grade, Sinopharm Chemical Reagent Co.) was added to remove water, and the supernatant was used for measurements.

The clam samples were dried with $10 \mathrm{~g}$ anhydrous sodium sulfate, then extracted twice ultrasonically with $25 \mathrm{~mL}$ n-hexane : acetone (1:1 $\mathrm{v}: \mathrm{v})$ mixture solution. After centrifugation at $6000 \mathrm{rpm}$ for $10 \mathrm{~min}$, the supernatant was evaporated to near dryness by rotary evaporator, and then re-dissolved in $5 \mathrm{~mL}$-hexane. Next, $3 \mathrm{~mL}$ of concentrated sulfuric acid (98\%, HPLC grade, Sinopharm Chemical Reagent Co.) were added, and the samples were vortexed for $3 \mathrm{~min}$ and then centrifuged at room temperature and $6000 \mathrm{rpm}$ for $20 \mathrm{~min}$. Five milliliters of $20 \mathrm{~g} / \mathrm{L}$ anhydrous sodium sulfate solution were then added to the supernatant, which was allowed to settle. The supernatant was subjected to a stream of nitrogen gas at $40{ }^{\circ} \mathrm{C}$ and re-dissolved in n-hexane. After removing the water with anhydrous sodium sulfate, the supernatant was used for BDE-209 measurements.

An Agilent 7890B gas chromatographer (with EI source) and 5977 mass spectrometer (Agilent Technologies, Santa Clara, CA, USA) were used to determine BDE-209 concentrations in splitless mode. The injection temperature was $280^{\circ} \mathrm{C}$, the flow rate was $1.5 \mathrm{~mL} / \mathrm{min}$, and the injection volume was $2 \mu \mathrm{L}$. The temperature of the ion source and quadrupole were $230{ }^{\circ} \mathrm{C}$ and $150{ }^{\circ} \mathrm{C}$, respectively. High-sensitivity tuning of selected ion monitoring mode was applied. The charge to mass ratio of the quantitative ion was $799.5 \mathrm{~m} / \mathrm{z}$, and the charge to mass ratios of the qualitative ions were 641.5 and $721.5 \mathrm{~m} / \mathrm{z}$.

\subsection{Analysis of mRNA expression levels}

Total RNA was extracted from $M$. veneriformis digestive glands using a TRIzol kit (Invitrogen, Carlsbad, CA, USA). After DNase digestion, cDNA was synthesized using oligo $\mathrm{dT}_{(18)}$ primers (Promega, Madison, WI, USA) and M-MLV reverse transcriptase (Promega). cDNA was amplified using a SYBR Green qRT-PCR kit (Applied Biosystems, Foster City, CA, USA) and an ABI PRISM 7500 real-time PCR system (Applied Biosystems), and a dissolution curve was generated. PCR conditions were set as follows: Pre-denaturation at $95^{\circ} \mathrm{C}$ for $5 \mathrm{~min}, 1$ cycle; denaturation at $95^{\circ} \mathrm{C}$ for $15 \mathrm{~s}$; annealing at $60^{\circ} \mathrm{C}$ for $30 \mathrm{~s}, 40$ cycles. Due to its stable expression, $\beta$-actin was used as the internal reference. Table 1 lists the primers used in the experiment. The detailed procedure was published previously (Fang et al., 2010).

\subsection{Determination of enzyme activity and MDA contents}

Samples were incubated in an ice-water bath, and $0.1 \mathrm{M}$ Tris $-\mathrm{HCl}$ buffer (pH 7.4, containing 1 mM EDTA, Sinopharm Chemical Reagent Co.) was added at a ratio of 1:9 (w:v), then homogenized for $1 \mathrm{~min}$ intermittently with a homogenizer (IKA T10, Staufen im Breisgau, Germany) at a rotation speed of $18,000 \mathrm{rpm}$. The homogenate was centrifuged at $4{ }^{\circ} \mathrm{C}$ and $13,000 \times g$ for $30 \mathrm{~min}$. The enzymatic activities of SOD, CAT, and GPx and MDA contents in the supernatant were determined using kits from Nanjing Jiancheng Bio-Engineering Institute Co., Ltd. (Nanjing, China), and the absorption of the color product was measured by spectrophotometry (WFZ UV-2800AH, Unico, Dayton, NJ,

Table 1

Primers used in this study.

\begin{tabular}{ll}
\hline Primer name & Sequence $\left(5^{\prime} \rightarrow 3^{\prime}\right)$ \\
\hline SODF (forward) & CACATTTCAATCCCGGTGGTA (Fang et al., 2010) \\
SODR (reverse) & AGCATGCACCACAACTGTCCT (Fang et al., 2010) \\
CATF (forward) & TGTGGGTGGAGAATCAGGCTCT (Dong et al., 2019) \\
CATR (reverse) & TATTATTGCCAACCATGTCCCAGT (Dong et al., 2019) \\
GPxF (forward) & GCGAGCCTTGGATTCATTGT (Dong et al., 2019) \\
GPxR (reverse) & AACAATGGAAAGTTTGGTACAAAG (Dong et al., 2019) \\
$\beta$-actinF (forward) & TCGGCAGTGGTTGTGAAAGAGT (Fang et al., 2010) \\
$\beta$-actin (reverse) & GATTGGATTTGGCTGGTAGAGAT (Fang et al., 2010) \\
\hline
\end{tabular}

USA). The SOD activity unit was defined as the amount of enzyme corresponding to $50 \%$ inhibition of the color production per milligram of tissue protein. The CAT activity unit was defined as the amount of enzyme required to decompose $1 \mu \mathrm{moL}$ of hydrogen peroxide per second per milligram of tissue protein. The GPx enzyme activity unit was defined as the amount of enzyme required to reduce glutathione concentrations by $1 \mu \mathrm{moL} / \mathrm{L}$ per milligram of tissue protein. MDA content was expressed as the mole number of MDA per milligram of tissue protein.

\subsection{Data analysis}

qPCR results were analyzed by SDS 2.0 (Applied Biosystems), and mRNA expression levels were calculated by the $2^{-\Delta \Delta C T}$ method (Livak and Schmittgen, 2001). The results were expressed as mean \pm standard deviation (SD). In order to identify the difference between the experimental groups, all the data were analyzed by repeated measures analyses of variance (rANOVA) using SPSS (version 13.0; IBM, Armonk, NY, USA). BDE-209 dose $(0,0,0.1,1$, and $10 \mu \mathrm{g} / \mathrm{L})$ was used as the between subjects-factors and duration $(0,1,3,5,7$, and $10 \mathrm{~d})$ was used as the within subjects-factors. The least significant differences (LSD) test was performed with a significance level of $P<0.05$. To investigate possible correlations between antioxidant response and BDE-209 concentration, Pearson's correlation was analyzed individually on the variables obtained at every sampling time. Two-tailed test was used and significant differences were considered statistically significant when $P<0.05$.

\section{Results}

\subsection{BDE-209 concentrations in seawater and clams}

The detection limits for BDE-209 in seawater and biological samples were $150 \mathrm{ng} / \mathrm{L}$ and $25 \mu \mathrm{g} / \mathrm{kg}$, respectively. No BDE-209 was detected in the seawater and biological samples from the control group and solvent control group, or in seawater from $0.1 \mu \mathrm{g} / \mathrm{L}$ group. After $24 \mathrm{~h}, \mathrm{BDE}-209$ concentrations dropped to $11.09 \%, 6.99 \%, 63.78 \%$, and $46.93 \%$ of the initial values in 1 and $10 \mu \mathrm{g} / \mathrm{L}$ exposure groups and 1 and $10 \mu \mathrm{g} / \mathrm{L}$ blank groups, respectively (Table 2). Within $24 \mathrm{~h}$ of exposure to 1 and $10 \mathrm{ug} /$ $\mathrm{L}$, the absorption of BDE-209 by clams accounted for $52.69 \%$ and $39.94 \%$ decrease of the water concentrations, respectively. BDE-209 accumulation in $M$. veneriformis was concentration-dependent, and peaked in $10 \mu \mathrm{g} / \mathrm{L}$ group on day 7 . After 3 days of recovery in clean seawater, BDE-209 accumulation decreased significantly to $54.38 \%$, $48.09 \%$, and $64.12 \%$ of the accumulation on day 7 in $0.1,1$, and $10 \mu \mathrm{g} /$ L groups, respectively.

\subsection{SOD mRNA expression and activity}

BDE-209 elevated mRNA expression and activity of SOD (Fig. 1). Both exposure dose and duration had significant effect on SOD (Table S1). In the clams exposed to 0.1 and $1 \mu \mathrm{g} / \mathrm{L}$ BDE-209, mRNA expression and activity of SOD increased in time-dependent manner and peaked on day 7. In clams exposed to $10 \mu \mathrm{g} / \mathrm{L} \mathrm{BDE}-209$, SOD showed a biphasic response and peaked on day 5. SOD mRNA expression exhibited dosedependent increase. After 3 days of recovery in clean seawater, mRNA expression of SOD returned to the control level in all the exposure groups; SOD activity decreased and was still significantly higher than the control level in 1 and $10 \mu \mathrm{g} / \mathrm{L}$ groups. SOD mRNA expression was positively correlated with SOD activity $(P<0.05)$ at each sampling time during exposure period (Table S2); no significant correlation was found on day $10(P>0.05)$.

\subsection{CAT mRNA expression and activity}

BDE-209 could induce the elevation of CAT mRNA expression and 
Table 2

BDE-209 concentrations in seawater and clams.

\begin{tabular}{|c|c|c|c|c|}
\hline \multirow{2}{*}{$\begin{array}{l}\text { Nominal concentration } \\
\text { in seawater }(\mu \mathrm{g} / \mathrm{L})\end{array}$} & \multicolumn{2}{|c|}{ Measured concentration in seawater (ng/L) } & \multicolumn{2}{|c|}{ Measured concentration in clams ( $\mu \mathrm{g} / \mathrm{kg}$ ww) } \\
\hline & $\mathrm{Oh}$ & $24 \mathrm{~h}$ & $7 \mathrm{~d}$ & $10 \mathrm{~d}$ \\
\hline 0 (Control) & n.d. & n.d. & n.d. & n.d. \\
\hline 0 (Solvent control) & n.d. & n.d. & n.d. & n.d. \\
\hline 0.1 & n.d. & n.d. & $139.73 \pm 13.46$ & $75.98 \pm 9.56$ \\
\hline 1 & $672.09 \pm 27.86$ & $74.52 \pm 7.84$ & $164.51 \pm 21.59$ & $79.72 \pm 17.10$ \\
\hline 10 & $5958.33 \pm 333.01$ & $416.78 \pm 72.49$ & $643.82 \pm 114.72$ & $410.25 \pm 55.82$ \\
\hline 0.1 (Blank group) & n.d. & n.d. & - & - \\
\hline 1 (Blank group) & $690.15 \pm 53.27$ & $440.18 \pm 60.34$ & - & - \\
\hline 10 (Blank group) & $5725.32 \pm 565.70$ & $2687.15 \pm 234.47$ & - & - \\
\hline
\end{tabular}

n.d. $=$ not detected.
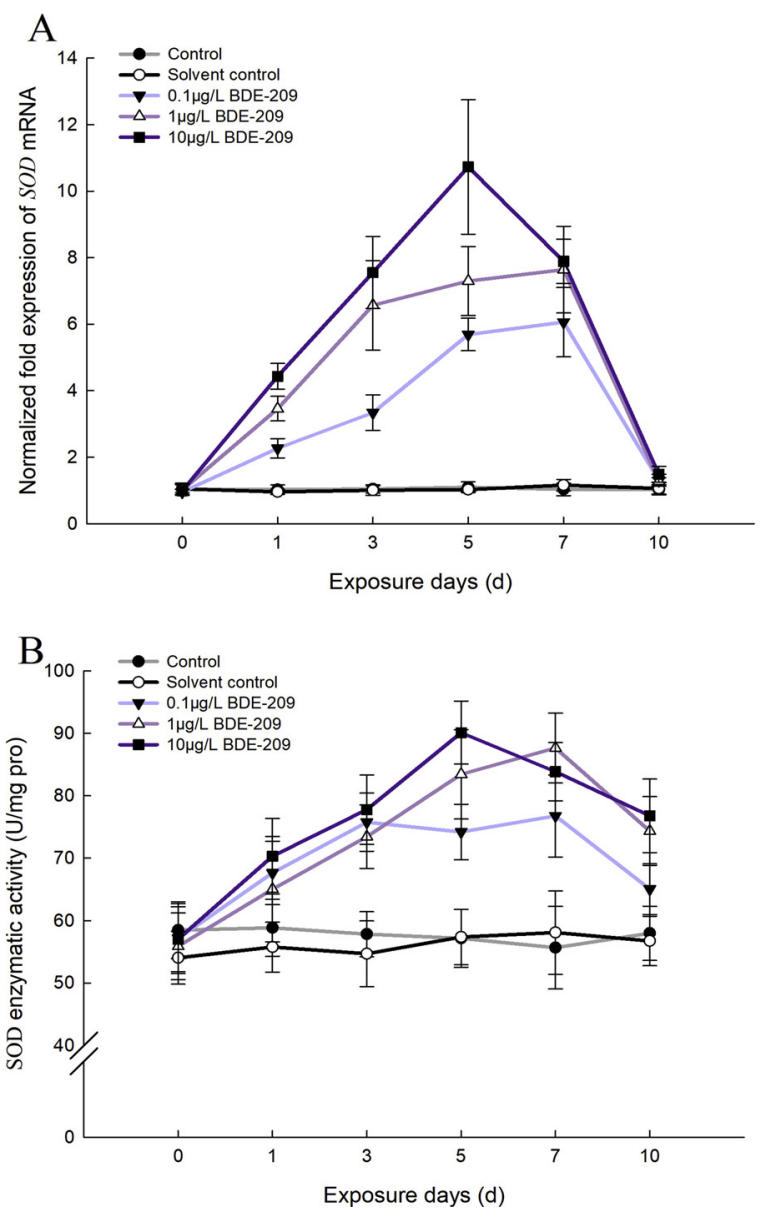

Fig. 1. Superoxide dismutase (SOD) mRNA expression (A) and activity (B) in the digestive gland of Mactra veneriformis exposed to BDE-209 $(0.1,1$, and $10 \mu \mathrm{g} / \mathrm{L}$ ) for 7 days and recovered in clean seawater for 3 days. Control group and solvent control group were also set up. Data represent means \pm standard deviation $(n=3)$.

activity (Fig. 2). Both dose and duration could significantly affect CAT response (Table S1). CAT mRNA expression and activity started to increase significantly on day 3 and on day 1 , respectively, and peaked on day 7. CAT mRNA expression increased in time-dependent manner. CAT activity increased in time- and dose-dependent manner. After 3 days of recovery in clean seawater, CAT mRNA expression in all the exposure groups subsided to control levels, and enzyme activity decreased but was still significantly higher than the control level. The correlation between CAT gene expression and enzymatic activity changed with duration (Table S2).
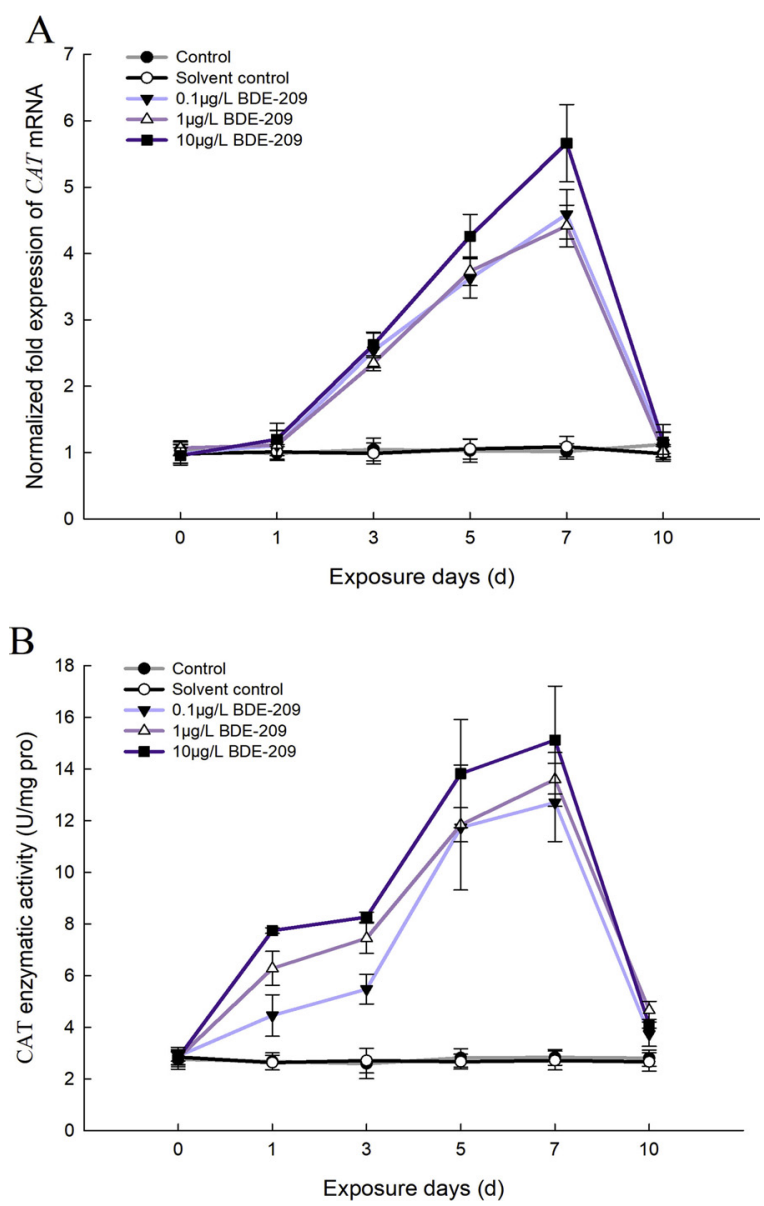

Fig. 2. Catalase (CAT) mRNA expression (A) and activity (B) in the digestive gland of Mactra veneriformis exposed to BDE-209 (0.1, 1, and $10 \mu \mathrm{g} / \mathrm{L})$ for 7 days and recovered in clean seawater for 3 days. Control group and solvent control group were also set up. Data represent means \pm standard deviation $(n=3)$.

\subsection{GPX mRNA expression and activity}

Both dose and duration could significantly affect mRNA expression and activity of GPx (Table S1). In the exposure groups, GPx expression increased significantly from day 3 , peaked on day 5 , and recovered to control levels after 3 days in clean water (Fig. 3). In clams exposed to $0.1 \mu \mathrm{g} / \mathrm{L}$ BDE-209, GPx activity increased significantly from day 3 and peaked on day 5. In clams exposed to 1 and $10 \mu \mathrm{g} / \mathrm{L}$, GPx activity increased significantly on day 1 and peaked on days 5 and 3, respectively. There was no significant difference in GPx activity between exposure groups and the controls on day 7 or after recovery in clean water. The correlation between GPx mRNA expression and enzymatic activity 

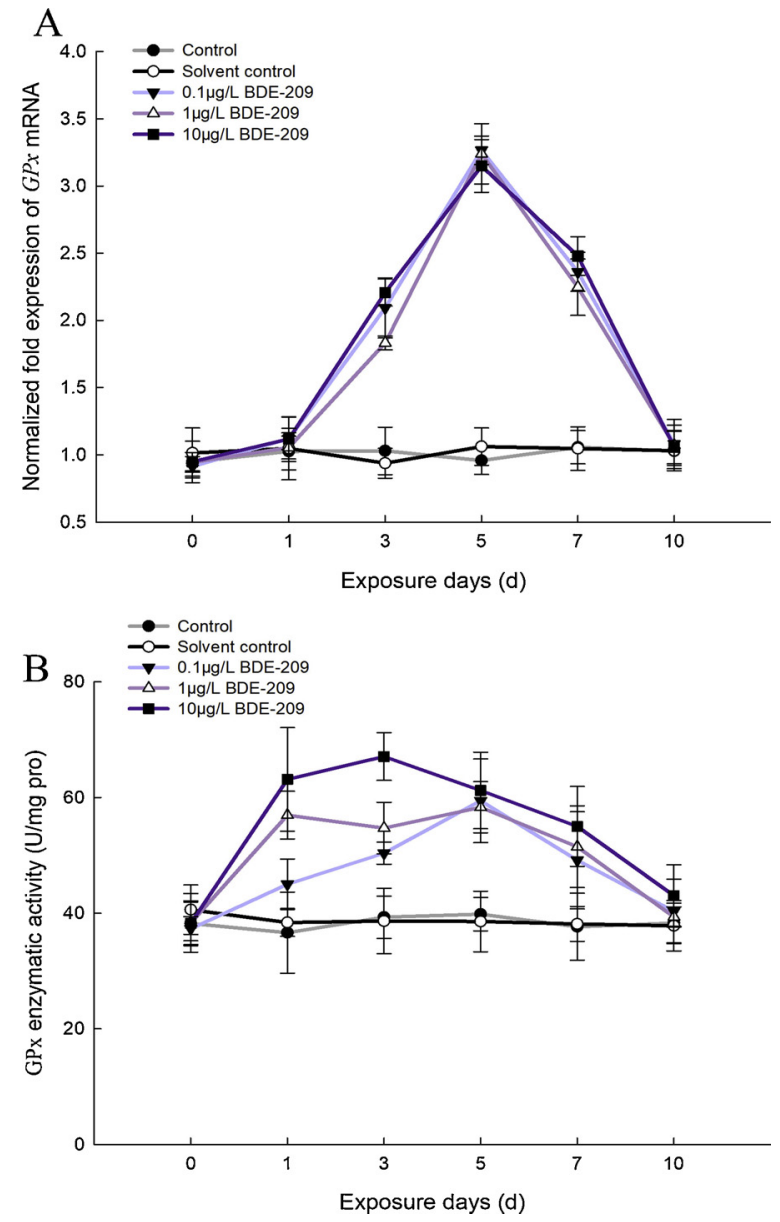

Fig. 3. Glutathione peroxidase (GPx) expression (A) and enzyme activity (B) in the digestive gland of Mactra veneriformis exposed to BDE-209 (0.1, 1, and $10 \mu \mathrm{g} / \mathrm{L}$ ) for 7 days and recovered in clean seawater for 3 days. Control group and solvent control group were also set up. Data represent means \pm standard deviation $(\mathrm{n}=3)$.

changed with duration (Table S2).

\subsection{MDA content following BDE-209 exposure}

MDA contents in the exposure groups increased significantly from day 3 , reached the climax on day 7 , and returned to the control level on day 10 (Fig. 4). The increase exhibited time- and dose-dependent manner.

\section{Discussion}

\subsection{BDE-209 concentrations in seawater and bioaccumulation in clams}

BDE-209 concentrations in seawater of the exposure groups were $57.25 \%-69.01 \%$ of the nominal concentrations after spiking of the pollutants. A toxicological study by waterborne exposure in the rotifer Brachionus plicatilis reported that BDE-209 concentrations in seawater measured $41.5 \%$ of the set concentration (Zhang et al., 2016b). In a zebrafish study, BDE-209 concentrations in water were about $80 \%$ of the nominal exposure concentrations (Zhu et al., 2016), while a study in M. galloprovincialis found much lower BDE-209 concentrations in seawater, of only $0.035 \%-0.15 \%$ of the nominal concentrations (Barón et al., 2016). Because of the high lipophilicity of PBDEs, their solubility in water is low, requiring a cosolvent. In this study and the reported work in B. plicatilis and zebrafish, DMSO was used as cosolvent, while acetone was used in the study in $M$. galloprovincialis. The solubility of

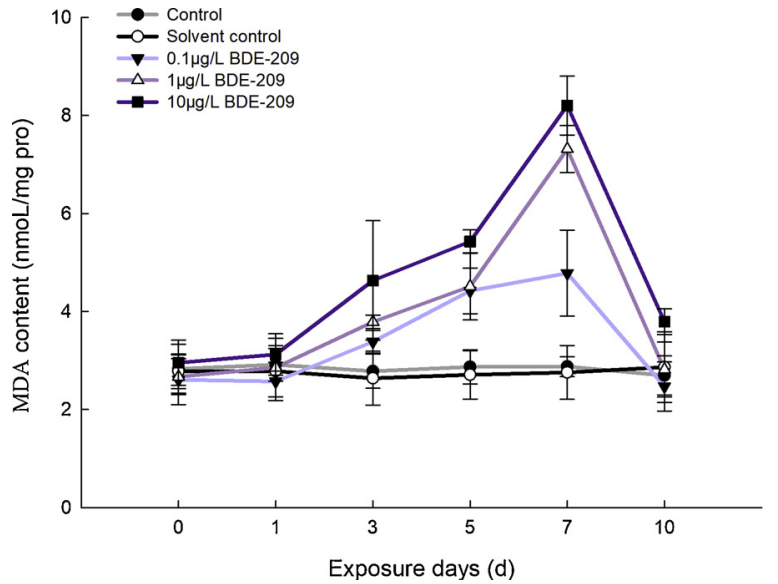

Fig. 4. Malondialdehyde (MDA) content in the digestive gland of Mactra veneriformis exposed to BDE-209 $(0.1,1$, and $10 \mu \mathrm{g} / \mathrm{L})$ for 7 days and recovered in clean seawater for 3 days. Control group and solvent control group were also set up. Data represent means \pm standard deviation $(n=3)$.

BDE-209 in water may vary by solvent, and different measurement methods may also account for the different ratios between the actual and nominal concentrations. BDE-209 concentrations in seawaters decreased with time. Same scenario was also found in other researches (Vidal-Liñá et al., 2015; Barón et al., 2016). Uptake by clams could not fully explain the decrease of BDE-209 concentrations. $36.22 \%$ and $53.07 \%$ of BDE-209 was lost in 1 and $10 \mathrm{ug} / \mathrm{L}$ groups within $24 \mathrm{~h}$, which might be due to the absorption of BDE-209 by particulates and volatilization of BDE-209.

Bioaccumulation in $M$. veneriformis was positively correlated with the exposure concentration, which indicated that the accumulation of BDE-209 occurred in the test clam under set concentrations and the accumulation depended on exposure concentration. Pollutants were taken up into the body of filter feeding shellfish while filtering. Each mussel M. galloprovincialis could accumulate 1.9, 1.7, and 1.6 ug BDE209 after exposure to $0.02,0.03$, and $0.3 \mu \mathrm{g} / \mathrm{L}$ BDE-209 for 6 days (Barón et al., 2016). The bioaccumulation in M. galloprovincialis was on the same order as that in $M$. veneriformis. Fishes take up and accumulate BDE-209 from water through gill and skin. When exposed to 0.1 and $1 \mu \mathrm{g} / \mathrm{L}$ BDE-209 for 15 days, the Japanese medaka $O$. latipes accumulated 53.6 and $36.2 \mathrm{ng} / \mathrm{g}$ wet weight BDE-209, respectively (Luo et al., 2013), which was less than the bioaccumulation observed in our study. Thus, $M$. veneriformis is able to accumulated BDE-209 efficiently, making it as a suitable model organism for studying the toxicological effects of BDE-209. After recovery in clean seawater for 3 days, BDE209 contents in $M$. veneriformis decreased considerably. Depuration of contaminant by aquatic organisms has been reported in previous studies and the depuration period varied with species and contaminant (Vidal-Liñá et al., 2015; Aouini et al., 2018). The elimination of BDE209 in M. veneriformis was probably due to the case that highly brominated PBDEs are more likely to be metabolized. Compared with low brominated congeners, highly brominated congeners had shorter halflife and faster elimination rates (Feng et al., 2012). The metabolism in fishes has shown that BDE-209 could be readily metabolized into debrominated PBDEs, methoxylated PBDEs and hydroxylated BDEs (Luo et al., 2013). BDE-209 was also easily biodegraded into lower brominated PBDEs in invertebrate earthworms (Zhang et al., 2014). However, the metabolism of BDE-209 was not clear in bivalves and should be studied further.

\subsection{Effects of BDE-209 on the antioxidant system}

A dominant PBDE congener in the environment, BDE-209 has been shown to cause oxidative stress in human erythrocytes, rats, 
earthworms, rotifers, goldfish, etc. (Feng et al., 2013; Milovanovic et al., 2015; Hu et al., 2016; Zhang et al., 2016a; Chi et al., 2017). Few studies have concerned on the oxidative stress caused by BDE-209 in marine bivalves, and should be supplemented. MDA is a product of lipid peroxidation, and is a sensitive marker of oxidative damage caused by excessive production of ROS (Sies, 2015). Since ROS could be induced by PBDEs in many organisms (Zhang et al., 2016a; Jiang et al., 2017), the overproduction of ROS caused by BDE-209 was presumed to resulted in the increase of MDA content in M. veneriformis. MDA contents increased with exposure duration and dose, suggesting that the peroxidation products of unsaturated fatty acids continued to accumulate in $M$. veneriformis, increasing the degree of oxidative damage. The test clam suffered continuous oxidative damage and could not efficiently resist the stress. Oxidative stress was reported as one of the important pathways by which PBDEs affect biological function in organisms (Chi et al., 2017; Jiang et al., 2017). The oxidative stress caused by BDE-209 in $M$. veneriformis might affect antioxidant system. The recovery of MDA content to the control level after 3 days of depuration indicated that the oxidative damage was repaired, which was related to the elimination of BDE-209.

The antioxidant system protects organisms from oxidative damage, and SOD, CAT, and GPx are important antioxidant enzymes. SOD catalyzes the superoxide anion $\left(\mathrm{O}_{2}{ }^{-} \cdot\right)$ into hydrogen peroxide $\left(\mathrm{H}_{2} \mathrm{O}_{2}\right)$, CAT catalyzes the decomposition of $\mathrm{H}_{2} \mathrm{O}_{2}$ to water and oxygen, and GPx catalyzes the reduction of $\mathrm{H}_{2} \mathrm{O}_{2}$ and a variety of organic hydroperoxides. The three enzymes maintain the dynamic balance of ROS production and elimination (Roversi et al., 2006), which is vulnerable to external stresses however. BDE-209 exposure elevated mRNA expression and enzymatic activities of SOD, CAT, and GPx, affecting the antioxidant system in $M$. veneriformis. The significant correlation between the responses of SOD, CAT, and GPx and MDA contents suggested that oxidative stress was responsible for these antioxidant responses and was the possible mechanism of toxicity of BDE-209. The gene expression of antioxidant enzymes might increase via ROS mediated pathway (Fatima and Ahmad, 2005). The increase of enzymatic activity might be due to either de novo synthesis of corresponding protein required by ROS production or the induction of gene expression (Verma and Dubey, 2003).

Antioxidant response to BDE-209 showed different pattern in $M$. veneriformis according to the enzyme type and exposure dose. At the transcriptional level, SOD responded earlier than CAT and GPx, which indicated that SOD acted as the first defense line against oxidative stress, while CAT and GPx intervened later. This scenario was consistent with their biological functions. The sequential involvement of these antioxidant enzymes in combating oxidative stress were also observed in the oyster Crassostrea madrasensis (Shenai-Tirodkar et al., 2017) and the earthworm Eisenia fetida (Hu et al., 2016). Overall, mRNA expression and activity of SOD, CAT, and GPx increased till peak day, which is considered as the universal protective response to stress (Dafre et al., 2004). The antioxidant enzymes were activated to cope with oxidative stress caused by BDE-209. No significant impact of BDE-209 on MDA content before day 3 also supported the effective scavenging of ROS by antioxidant enzymes. SOD response in high-dose group and GPx response in the entire exposure groups decreased after the peak, perhaps because SOD and GPx were degraded by ROS or over utilized to overcome with BDE-209 toxicity (Shenai-Tirodkar et al., 2017). The decrease suggested the impairment of antioxidant enzymes. Then, the ability of SOD to degrade $\mathrm{O}_{2}{ }^{-}$. and the ability of GPx to degrade $\mathrm{H}_{2} \mathrm{O}_{2}$ and organic peroxide were inhibited, resulting in the unbalance between ROS production and scavenging and the enhancement of lipid peroxidation. The oxidative stress could not be overcome and oxidative damage occurred, which was evidenced by the significant increase of MDA content on day 5 and day 7. Similar findings were reported in the bivalve Anodonta woodiana (Xia et al., 2016) and the rotifer B. plicatilis (Zhang et al., 2016a) under BDE-209 exposure.

The correlation between SOD, CAT, and GPX expression and their corresponding enzymatic activities changed with duration. Divergences were also reported in previous researches ( $\mathrm{Li}$ et al., 2014; Hu et al., 2016). The significant positive correlation suggested the good match between mRNA expressions and enzymatic activities. The increased transcription might support the synthesis of the antioxidant enzymes required to scavenge ROS ( $\mathrm{Hu}$ et al., 2016). The mismatch between mRNA expressions and enzymatic activities might be attributed to the time window existing between the mRNA transcription and translation. BDE-209 might affect post-transcriptional regulation and translational efficiency of antioxidant enzymes. Some pollutants were able to posttranscriptionally modify protein expression. For example, methylmercury and mercury chloride interfered with RNA splicing (Li et al., 2018). Some organic pollutants could inactivate protein by interaction with protein and inhibit protein synthesis by disrupting ribosomal function (Tu and McCalla, 1976). It has been proven that BDE-209 could bind to AhcE and form inactive derivatives (Wang et al., 2018). Can BDE-209 bind to these antioxidant enzymes? The exact mechanism of BDE-209 involved in post transcriptional and translational regulation should be studied next step. Besides, different isoforms of antioxidant enzyme family might also contribute to the discrepancy (Zhang et al., 2018). Previous studies have reported that two CAT homologs existing in oyster Crassostrea hongkongensis (Zhang et al., 2011) and two subtypes of GPX gene existing in Pacific oyster Crassostrea gigas (David et al., 2007; Jo et al., 2008). Accordingly, M. veneriformis possibly has other types of CAT and GPx genes. In this study, gene expression of a $C A T$ subtype and a GPX subtype was tested and the enzyme activity consisting of all isozymes was determined. It could also explain that CAT and GPx activities increased significantly on the first day after exposure, while the expression of CAT and GPX did not change significantly.

Molecular markers indicate the biological effects of pollutant stresses, which can be used as biomarkers of exposure, especially at low concentrations. Antioxidant enzymes are sensitive biomarkers of aquatic pollution, and have been widely studied in aquatic organisms (Xie et al., 2014; Horion et al., 2015; Shenai-Tirodkar et al., 2017). In the present research, SOD, CAT, and GPx showed quick and sensitive response to BDE-209 stress with time- or dose-dependent manner. Their transcripts and activities reduced sharply after recovery in clean seawater. Especially, mRNA expression of SOD, CAT, and GPx subsided to the control level after 3 days of removal from contaminated seawater. Moreover, the fluctuation range of mRNA expression was larger than that of enzymatic activity. These findings suggested that mRNA expression might be more responsive than enzymatic activity. Transcription level reflects the immediate state of cells and quantifies the toxicity of potentially harmful substances (Brulle et al., 2010). Enzymatic activity indicates pollution from the physiological condition (Jemec et al., 2010). Transcripts and activities belong to genic and physiological endpoints, and always mismatched as discussed above. Thus, transcriptional and protein levels complement each other to provide comprehensive overview on ecotoxicological effect induced by contaminations. mRNA expressions and enzymatic activities would be used jointly as potential biomarkers of aquatic pollution in view of health status of organisms.

\section{Conclusion}

We assessed BDE-209 bioaccumulation and the response of the antioxidant system in $M$. veneriformis. The clams could accumulate BDE209 efficiently during exposure period and eliminate BDE-209 considerably after recovery in clean seawater. BDE-209 caused oxidative stress. The clams suffered more oxidative stress as MDA accumulated gradually over time. SOD, CAT, and GPx were activated and involved in resisting oxidative stress sequentially. In future, researches on the mechanism of antioxidant response to BDE-209 should be carried out. 


\section{Conflict of interest}

The authors declare that they have no conflict of interest.

\section{Acknowledgments}

This study was supported by grants from the National Natural Science Foundation of China (No. 41206120 and No. 31502173), the Development Plan of Science and Technology in Yantai (No. 2011062), the Ludong University Research Funding (No. 210-32040301), the Innovative Project of Undergraduate (201710451330, 201710451331, and 201710451332), and Marine and Fisheries Science and Technology Innovation Program of Shandong Province (2017YY04).

\section{Appendix A. Supplementary data}

Supplementary material related to this article can be found, in the online version, at doi:https://doi.org/10.1016/j.etap.2019.03.004.

\section{References}

Akortia, E., Okonkwo, J.O., Lupankwa, M., Osae, S.D., Daso, A.P., Olukunle, O.I. Chaudhary, A., 2016. A review of sources, levels and toxicity of polybrominated diphenyl ethers (PBDEs) and their transformation and transport in various environmental compartments. Environ. Rev. 24, 253-273. https://doi.org/10.1139/er-20150081.

Aouini, F., Trombini, C., Volland, M., Elcafsi, M., Blasco, J., 2018. Assessing lead toxicity in the clam Ruditapes philippinarum: bioaccumulation and biochemical responses. Ecotox. Environ. Safe. 158, 193-203. https://doi.org/10.1016/j.ecoenv.2018.04. 033.

Barón, E., Dissanayake, A., Vilà-Cano, J., Crowther, C., Readman, J.W., Jha, A.N., Eljarrat, E., Barceló, D., 2016. Evaluation of the genotoxic and physiological effects of decabromodiphenyl ether (BDE-209) and dechlorane plus (DP) flame retardants in marine mussels (Mytilus galloprovincialis). Environ. Sci. Technol. 50, 2700-2708. https://doi.org/10.1021/acs.est.5b05814.

Bricker, S., Lauenstein, G., Maruya, K., 2014. NOAA's Mussel Watch Program: incorporating contaminants of emerging concern (CECs) into a long-term monitoring program. Mar. Pollut. Bull. 81, 289-290. https://doi.org/10.1016/j.marpolbul.2013. 06.040.

Brulle, F., Morgan, A.J., Cocquerelle, C., Vandenbulcke, F., 2010. Transcriptomic underpinning of toxicant-mediated physiological function alterations in three terrestrial invertebrate taxa: a review. Environ. Pollut. 158, 2793-2808. https://doi.org/10 1016/j.envpol.2010.06.019.

Chen, L., Yu, K., Huang, C., Yu, L., Zhu, B., Lam, P.K.S., Lam, J.C.W., Zhou, B., 2012. Prenatal transfer of polybrominated diphenyl ethers (PBDEs) results in developmental neurotoxicity in zebrafish larvae. Environ. Sci. Technol. 46, 9727-9734. https://doi.org/10.1021/es302119g.

Chi, Z., Tan, S., Li, W., Wen, Z., Song, X., Wang, M., 2017. In vitro cytotoxicity of decabrominated diphenyl ether (PBDE-209) to human red blood cells (hRBCs). Chemosphere 180, 312-316. https://doi.org/10.1016/j.chemosphere.2017.04.032.

Cristale, J., Garcia Vazquez, A., Barata, C., Lacorte, S., 2013. Priority and emerging flame retardants in rivers: occurrence in water and sediment, Daphnia magna toxicity and risk assessment. Environ. Int. 59, 232-243. https://doi.org/10.1016/j.envint.2013. 06.011 .

Dafre, A.L., Medeiros, I.D., Muller, I.C., Ventura, E.C., Bainy, A.C., 2004. Antioxidant enzymes and thiol/disulfide status in the digestive gland of the brown mussel Perna perna exposed to lead and paraquat. Chem. Biol. Interact. 149, 97-105. https://doi. org/10.1016/j.cbi.2004.07.002.

David, E., Tanguy, A., Moraga, D., 2007. Peroxiredoxin 6 gene: a new physiological and genetic indicator of multiple environmental stress response in Pacific oyster Crassostrea gigas. Aquat. Toxicol. 84, 389-398. https://doi.org/10.1016/j.aquatox. 2007.06.017.

de Wit, C.A., Herzke, D., Vorkamp, K., 2010. Brominated flame retardants in the Arctic environment-trends and new candidates. Sci. Total Environ. 408, 2885-2918. https://doi.org/10.1016/j.scitotenv.2009.08.037.

Dong, S., Yang, Y., Cheng, B., Ren, C., Zhang, H., Xu, H., Zhu, N., Wang, W., Dang, Y., Li, M., Chen, J., Wang, K., Zhang, L., Fang, Y., 2019. Responses of antioxidant defenses in the clam Mactra veneriformis to 2,2',4,4'-tetrabromodiphenyl ether exposure. Comp. Biochem. Physiol. C Toxicol. Pharmacol. 217, 98-105. https://doi.org/10. 1016/j.cbpc.2018.12.003.

Fang, Y., Yang, H., Wang, T., Liu, B., Zhao, H., Chen, M., 2010. Metallothionein and superoxide dismutase responses to sublethal cadmium exposure in the clam Mactra veneriformis. Comp. Biochem. Physiol. C Toxicol. Pharmacol. 151, 325-333. https:// doi.org/10.1016/j.cbpc.2009.12.005.

Fatima, R.A., Ahmad, M., 2005. Certain antioxidant enzymes of Allium cepa as biomarkers for the detection of toxic heavy metals in wastewater. Sci. Total Environ. 346, 256-273. https://doi.org/10.1016/j.scitotenv.2004.12.004.

Feng, C., Xu, Y., Zhao, G., Zha, J., Wu, F., Wang, Z., 2012. Relationship between BDE 209 metabolites and thyroid hormone levels in rainbow trout (Oncorhynchus mykiss).
Aquat. Toxicol. 122-123, 28-35. https://doi.org/10.1016/j.aquatox.2012.05.008.

Feng, M., Li, Y., Qu, R., Wang, L., Wang, Z, 2013. Oxidative stress biomarkers in freshwater fish Carassius auratus exposed to decabromodiphenyl ether and ethane, or their mixture. Ecotoxicology 22, 1101-1110. https://doi.org/10.1007/s10646-0131097-2.

Guan, Y., Wang, J., Ni, H., Luo, X., Mai, B., Zeng, E.Y., 2007. Riverine inputs of polybrominated diphenyl ethers from the Pearl River Delta (China) to the coastal ocean. Environ. Sci. Technol. 41, 6007-6013. https://doi.org/10.1021/es070782x.

Han, Z., Li, Y., Zhang, S., Song, N., Xu, H., Dang, Y., Liu, C., Giesy, J.P., Yu, H., 2017. Prenatal transfer of decabromodiphenyl ether (BDE-209) results in disruption of the thyroid system and developmental toxicity in zebrafish offspring. Aquat. Toxicol. 190, 46-52. https://doi.org/10.1016/j.aquatox.2017.06.020.

He, J., Yang, D., Wang, C., Liu, W., Liao, J., Xu, T., Bai, C., Chen, J., Lin, K., Huang, C., Dong, Q., 2011. Chronic zebrafish low dose decabrominated diphenyl ether (BDE209) exposure affected parental gonad development and locomotion in F1 offspring. Ecotoxicology 20, 1813-1822. https://doi.org/10.1007/s10646-011-0720-3.

Horion, S., Thomé, J.P., Gismondi, É., 2015. Changes in antitoxic defense systems of the freshwater amphipod Gammarus pulex exposed to BDE-47 and BDE-99. Ecotoxicology 24, 959-966. https://doi.org/10.1007/s10646-015-1438-4.

Hu, S., Zhang, W., Li, J., Lin, K., Ji, R., 2016. Antioxidant and gene expression responses of Eisenia fetida following repeated exposure to BDE209 and $\mathrm{Pb}$ in a soil-earthworm system. Sci. Total Environ. 556, 163-168. https://doi.org/10.1016/j.scitotenv.2016. 02.194.

Jemec, A., Drobne, D., Tisler, T., Sepcic, K., 2010. Biochemical biomarkers in environmental studies-lessons learnt from enzymes CAT, glutathione S-transferase and cholinesterase in two crustacean species. Environ. Sci. Pollut. Res. 17, 571-581. https:// doi.org/10.1007/s11356-009-0112-x.

Jiang, Y., Tang, X., Sun, T., Wang, Y., 2017. BDE-47 exposure changed the immune function of haemocytes in Mytilus edulis: an explanation based on ROS-mediated pathway. Aquat. Toxicol. 182, 58-66. https://doi.org/10.1016/j.aquatox.2016.11. 010 .

Jin, J., Liu, W., Wang, Y., Tang, X.Y., 2008. Levels and distribution of polybrominated diphenyl ethers in plant, shellfish and sediment samples from Laizhou Bay in China Chemosphere 71, 1043-1050. https://doi.org/10.1016/j.chemosphere.2007.11.041.

Jo, P.G., Choi, Y.K., Choi, C.Y., 2008. Cloning and mRNA expression of antioxidant enzymes in the Pacific oyster, Crassostrea gigas in response to cadmium exposure. Comp. Biochem. Physiol. C Toxicol. Pharmacol. 147, 460-469. https://doi.org/10.1016/j. cbpc.2008.02.001.

Krieger, L.K., Szeitz, A., Bandiera, S.M., 2016. Evaluation of hepatic biotransformation of polybrominated diphenyl ethers in the polar bear (Ursus maritimus). Chemosphere 146, 555-564. https://doi.org/10.1016/j.chemosphere.2015.11.120.

Li, J., Zhou, L., Lin, X., Yi, Z., Al-Rasheid, K.A., 2014. Characterizing dose-responses of catalase to nitrofurazone exposure in model ciliated protozoan Euplotes vannus for ecotoxicity assessment: enzyme activity and mRNA expression. Ecotox. Environ. Safe. 100, 294-302. https://doi.org/10.1016/j.ecoenv.2013.08.021.

Li, Y., He, B., Gao, J., Liu, Q.S., Liu, R., Qu, G., Shi, J., Hu, L., Jiang, G., 2018. Methylmercury exposure alters RNA splicing in human neuroblastoma SK-N-SH cells: implications from proteomic and post-transcriptional responses. Environ. Pollut. 238, 213-221. https://doi.org/10.1016/j.envpol.2018.03.019.

Livak, K.J., Schmittgen, T.D., 2001. Analysis of relative gene expression data using realtime quantitative PCR and the 2(-Delta Delta C(T)) method. Methods 25, 402-408. https://doi.org/10.1006/meth.2001.1262.

Luo, Q., Zha, J.M., Wang, Z., Wong, M.H., Cai, Z., 2013. Bioaccumulation and debromination of BDE-209 in Japanese medaka (Oryzias Latipes) when continuously exposed to environmental relevant concentrations. J. Environ. Sci. Heal. A. 48, 1349-1355. https://doi.org/10.1080/10934529.2013.781880.

Mai, B., Chen, S., Luo, X., Chen, L., Yang, Q., Sheng, G., Peng, P., Fu, J., Zeng, E.Y., 2005. Distribution of polybrominated diphenyl ethers in sediments of the Pearl River Delta and adjacent South China Sea. Environ. Sci. Technol. 39, 3521-3527. https://doi. org/10.1021/es048083x.

Milovanovic, V., Buha, A., Matovic, V., Curcic, M., Vucinic, S., Nakano, T., Antonijevic, B., 2015. Oxidative stress and renal toxicity after subacute exposure to decabrominated diphenyl ether in Wistar rats. Environ. Sci. Pollut. R. 25, 7223-7230. https://doi.org/10.1007/s11356-015-5921-5.

Mwangi, J.K., Lee, W.J., Wang, L.C., Sung, P.J., Fang, L.S., Lee, Y.Y., Chang-Chien, G.P., 2016. Persistent organic pollutants in the antarctic coastal environment and their bioaccumulation in penguins. Environ. Pollut. 216, 924-934. https://doi.org/10. 1016/j.envpol.2016.07.001.

Ramu, K., Kajiwara, N., Sudaryanto, A., Isobe, T., Takahashi, S., Subramanian, A., Ueno, D., Zheng, G.J., Lam, P.K.S., Takada, H., Zakaria, M.P., Viet, P.H., Rprudente, M., Tana, T.S., Tanabe, S., 2007. Asian mussel watch program: contamination status of polybrominated diphenyl ethers and organochlorines in coastal waters of Asian countries. Environ. Sci. Technol. 41, 4580-4586. https://doi.org/10.1021 es070380p.

Roscales, J.L., Muñoz-Arnanz, J., Ros, M., Vicente, A., Barrios, L., Jiménez, B., 2018. Assessment of POPs in air from Spain using passive sampling from 2008 to 2015. Part I: spatial and temporal observations of PBDEs. Sci. Total Environ. 634, 1657-1668. https://doi.org/10.1016/j.scitotenv.2018.03.043.

Roversi, F.M., Galdieri, L.C., Grego, B.H.C., Souza, F.G., Micheletti, C., Martins, A.M., D'Almeida, V., 2006. Blood oxidative stress markers in Gaucher disease patients. Clin. Chim. Acta 364, 316-320. https://doi.org/10.1016/j.cca.2005.07.022.

Sha, J., Wang, Y., Lv, J., Wang, H., Chen, H., Qi, L., Tang, X., 2015. Effects of two polybrominated diphenyl ethers (BDE-47, BDE-209) on the swimming behavior, population growth and reproduction of the rotifer Brachionus plicatilis. J. Environ. Sci. 28, 54-63. https://doi.org/10.1016/j.jes.2014.07.020.

Shenai-Tirodkar, P.S., Gauns, M.U., Mujawar, M.W.A., Ansari, Z.A., 2017. Antioxidant 
responses in gills and digestive gland of oyster Crassostrea madrasensis (Preston) under lead exposure. Ecotox. Environ. Safe. 142, 87-94. https://doi.org/10.1016/j. ecoenv.2017.03.056.

Shi, P., Dong, S., Zhang, H., Wang, P., Niu, Z., Fang, Y., 2018. Transcriptome profiling analysis of Mactra veneriformis by deep sequencing after exposure to 2,2',4,4'-tetrabromodiphenyl ether. J. Oceanol. Limn. 36 (2), 490-507. https://doi.org/10.1007/ s00343-018-6347-y.

Sies, H., 2015. Oxidative stress: a concept in redox biology and medicine. Redox Biol. 4, 180-183. https://doi.org/10.1016/j.redox.2015.01.002.

Stockholm Convention. http://www.pops.int/TheConvention/ThePOPs/TheNewPOPs.

Tu, Y., McCalla, D.R., 1976. Effect of nitrofurazone on bacterial RNA and ribosome synthesis and on the function of ribosomes. Chem. Biol. Interact. 14 (1-2), 81-91. https://doi.org/10.1016/0009-2797(76)90026-0.

Van Beneden, R.J., 1994. Molecular analysis of bivalve tumors: models for environmental/genetic interactions. Environ. Health Persp. 102 (Suppl. 12), 81-83. https:// doi.org/10.1289/ehp.94102s1281.

Verma, S., Dubey, R.S., 2003. Lead toxicity induces lipid peroxidation and alters the activities of antioxidant enzymes in growing rice plants. Plant Sci. 164, 645-655. https://doi.org/10.1016/s0168-9452(03)00022-0.

Vidal-Liñá, L., Bellas, J., Fumega, J., Beiras, R., 2015. Bioaccumulation of BDE-47 and effects on molecular biomarkers acetylcholinesterase, glutathione-S-transferase and glutathione peroxidase in Mytilus galloprovincialis mussels. Ecotoxicology 24, 292-300. https://doi.org/10.1007/s10646-014-1377-5.

Wang, Y., Liang, L., Shi, J., Jiang, G., 2005. Study on the contamination of heavy metals and their correlations in mollusks collected from coastal sites along the Chinese Bohai Sea. Environ. Int. 31 (8), 1103-1113. https://doi.org/10.1016/j.envint.2005.02.005.

Wang, S., Wu, C., Liu, Z., You, H., 2018. Studies on the interaction of BDE-47 and BDE209 with acetylcholinesterase (AChE) based on the neurotoxicity through fluorescence, UV-vis spectra, and molecular docking. Toxicol. Lett. 287, 42-48. https://doi. org/10.1016/j.toxlet.2018.01.018.

Xia, X., Huang, C., Zhang, D., Zhang, Y., Xue, S., Wang, X., Zhang, Q., Guo, L., 2016. Molecular cloning, characterization, and the response of $\mathrm{Cu} / \mathrm{Zn}$ superoxide dismutase and catalase to PBDE-47 and -209 from the freshwater bivalve Anodonta woodiana.
Fish Shellfish Immun. 51, 200-210. https://doi.org/10.1016/j.fsi.2016.02.025.

Xie, Z., Lu, G., Qi, P., 2014. Effects of BDE-209 and its mixtures with BDE-47 and BDE-99 on multiple biomarkers in Carassius auratus. Environ. Toxicol. Pharmacol. 38, 554-561. https://doi.org/10.1016/j.etap.2014.08.008.

Zhang, Y., Fu, D., Yu, F., Liu, Q., Yu, Z., 2011. Two catalase homologs are involved in host protection against bacterial infection and oxidative stress in Crassostrea hongkongensis. Fish Shellfish Immun. 31, 894-903. https://doi.org/10.1016/j.fsi.2011. 08.005 .

Zhang, W., Chen, L., Liu, K., Chen, L., Lin, K., Chen, Y., Yan, Z., 2014. Bioaccumulation of decabromodiphenyl ether (BDE209) in earthworms in the presence of lead (Pb). Chemosphere 106, 57-64. https://doi.org/10.1016/j.chemosphere.2014.01.059.

Zhang, J., Wang, Y., Sun, K.M., Fang, K., Tang, X., 2016a. A study of oxidative stress induced by two polybrominated diphenyl ethers in the rotifer Brachionus plicatilis. Mar. Pollut. Bull. 113, 408-413. https://doi.org/10.1016/j.marpolbul.2016.10.032.

Zhang, J., Wang, Y., Zhou, B., Sun, K.M., Tang, X., 2016b. Reproductive effects of two polybrominated diphenyl ethers on the rotifer Brachionus plicatilis. B. Environ. Contam. Tox. 97, 198-202. https://doi.org/10.1007/s00128-016-1832-5.

Zhang, H.C., Ma, K.X., Yang, Y.J., Shi, C.Y., Chen, G.W., Liu, D.Z., 2018. Molecular cloning, characterization, expression and enzyme activity of catalase from planarian Dugesia japonica in response to environmental pollutants. Ecotox. Environ. Safe. 165, 88-95. https://doi.org/10.1016/j.ecoenv.2018.08.083.

Zhao, A., Liu, H., Zhang, A., Wang, X., Zhang, H., Wang, H., 2011. Effect of BDE-209 on glutathione system in Carassius auratus. Environ. Toxicol. Phar. 32, 35-39. https:// doi.org/10.1016/j.etap.2011.03.004.

Zhu, B., Wang, Q., Shi, X., Guo, Y., Xu, T., Zhou, B., 2016. Effect of combined exposure to lead and decabromodiphenyl ether on neurodevelopment of zebrafish larvae. Chemosphere 144, 1646-1654. https://doi.org/10.1016/j.chemosphere.2015.10. 056.

Zota, A.R., Mitro, S.D., Robinson, J.F., Hamilton, E.G., Park, J.S., Parry, E., Zoeller, R.T., Woodruff, T.J., 2018. Polybrominated diphenyl ethers (PBDEs) and hydroxylated PBDE metabolites (OH-PBDEs) in maternal and fetal tissues, and associations with fetal cytochrome P450 gene expression. Environ. Int. 112, 269-278. https://doi.org/ 10.1016/j.envint.2017.12.030. 